\title{
Public Sector 'Modernisation': Examining the Impact of a Change Agenda on Local Government Employees in England
}

\begin{abstract}
Can public sector reform change service performance for the better? This is a hotly contested debate which carries significant theoretical and practical importance. In England, as in many countries, modernisation was at the heart of local government reform and represented an interpretation of New Public Management into a policy framework. This paper examines the role of the modernisation change agenda in England and what this has subsequently meant for "service improvement'. Drawing on both document analyses and qualitative interviews with local government employees, we find that while modernisation sought to establish continuous improvement, unintended consequences of modernisation have led to Staff Reductions, Skill Deficiencies, and Loss of a Competent Middle Core in local government, as well as performance outcomes creating an environment for Commissioning, Service Reduction, and Self-Policing. Implications for the lasting roles and behaviours of public managers affected by this national change agenda are discussed, and conclusions for theory and practice are drawn.
\end{abstract}

Key words: Modernisation, change agenda, new public management, local government, employees. 


\section{Introduction}

The view that public sector reform can change service performance for the better appears to be held by governments across the world (e.g. Haward and Zwart 2000; Torres 2004; Andrews 2010) and has come to typify the 'core NPM group' of countries: UK, Australia, New Zealand and, to an extent, the USA have all pursued service improvement aggressively (Christensen and Laegreid 2011). This has led to "one of the most hotly contested debates in public management today: is organisational performance improved by ambitious programmes of reform?" (Andrews 2010, p.599). Such reforms are typically badged as 'modernisation' and this trend has been observed either implicitly or explicitly across a range of countries and administrations including Australia and New Zealand (Christensen and Laegreid 2011). Tasmania's major reform process of 'modernisation' between 1990 and 1993 is a suitable case in point (Haward and Zwart 2000), as well as the service Tasmania reforms described by Blackburn (2014).

Modernisation of the English public sector was directed by New Labour during the 19972010 administrations. As Tichelar and Watts (2000, p.222) outline, the aim was "to make local authorities more open and democratically accountable to local populations, to increase strategic thinking and planning and to substantially improve performance management". This 'modernising' agenda represented a radical change for local government authorities as they moved away from notions of a smaller state and the role of the private sector of the previous Conservative administration, toward New Labour's interpretation of the principles of New Public Management (NPM). The aim of this paper is to examine in detail the role played by this modernisation change agenda in England and what this has subsequently meant for 'service improvement' by hearing from those responsible for the formulation and delivery of public services: public sector workers. 
Though NPM is a well-established phenomenon with broadly accepted core elements such as marketization, performance management, and the influence of private-sector practices (e.g. Hood 1991; Hood 1995; Ferlie et al. 1996; Osborne and McLaughlin 2002), New Labour's modernisation agenda was met with some disagreement as to whether it was descriptive or normative, i.e. an explicit methodology used to define action or merely a socially constructed concept that attempts to explain a broader direction (e.g. Lynn 1998; Goldfinch and Wallis 2010; Williams et al. 2012). Similarly, Stoker (2002) suggests there was a strong element of 'contrived randomness' to New Labour's modernisation agenda, which 'showered' local government with initiatives, grants, plans and strategies in order to provide a semi-chaotic state from which innovation and (self-managed) development could emerge. We will not advocate here for the validity of this argument, but rather observe that there remain multiple and conflicting interpretations of modernisation. This phenomenon, however, is a culturally observed one and, thus, there is a need to capture the underpinning values, beliefs, and intentions of modernisation if the effects of this change agenda are to be understood. This leads to our research questions:

1. What was the intention behind modernisation and how was it constructed?

2. What has been the legacy of this change agenda for public sector workers?

Informed by a critical discourse analysis perspective, which views language as an ideologically and socially constructed phenomenon, the language used under modernisation is deconstructed in order to address the first research question. To augment the critical discourse perspective, we draw on qualitative semi-structured interviews with public managers across local governments in England to examine the consequences of change in public sector organisations and to investigate the reactions and responses of public sector workers to this ambitious programme of reform. 
The findings reveal contradictions between the espoused (rhetoric) and the experienced situation (reality) and uncover emerging unintended consequences of modernisation revolving around staff reductions and the loss of a 'competent middle core' of experienced staff who have been and are still being replaced with inexperienced graduate trainees. Though a modernising government was described as one that freed public service so that it can build on its strengths to innovate and to rise to societal challenges, the net effect in stark contrast has been a loss of expertise and knowledge across public organisations and a drive for commissioning and service reduction.

Two core contributions are made to the public management and administration literatures. First, Andrews (2010) argues robustly that examining whether the implementation of significant management reforms leads to better or worse service outcomes is of substantial empirical and theoretical importance. This study directly addresses this knowledge void through a novel critical discourse analysis of modernisation policy coupled with rich qualitative insights to uncover the effects of modernisation on service improvement over time. Second, by exploring the legacy effects of modernisation for the public sector, we contribute new knowledge on the lasting roles and behaviours of public sector workers involved in, and affected by, a national change agenda, as called for by Kuipers et al. (2014).

\section{Approach}

With regard to our first research question: What was the intention behind modernisation and how was it constructed? There are a number of well-presented literature reviews on modernisation reform in the public management and administration literatures (see, for example: Haward and Zwart 2000; Laffin 2008; Andrews 2010). Rather than seek to repeat the same narrative here, we 
adopt a critical discourse approach (Fairclough 2000) to analyse the language used during modernisation in England. This approach provides insights into the layers of meaning behind the reform, which is necessary as without understanding the intentions that underpinned the largest change agenda in the contemporary history of English public sector reform, one cannot begin to interpret and understand the legacy effects of this change agenda on public sector workers.

Specifically, we perform a content analysis (Neuendorf 2002; Krippendorff 2004) and critical discourse analysis (Fairclough 2000; 2001; 2013) of the initial forewords for the four white papers that effectively capture the whole modernisation change period from inception to its demise, providing a complete policy review from the initial 'Modernising Government' White Paper (1999) through New Labour's mid-administration White Papers 'Strong and Prosperous Communities' (2006) and 'Communities in Control' (2008), to the Coalition Government's White Paper 'Open Public Services' (2011). An analysis of the key terms used in the forewords to these four white papers is presented to unpack the discourses operating and to examine the construction of modernisation language and rhetoric.

To address the second research question: What has been the legacy of this change agenda for public sector workers? We draw on data from 35 qualitative interviews with public managers (comprising senior and middle management) across six English local authorities, along with ethnographic field observations. Local authorities were selected using a deviant case method (David and Sutton 2011) based on 2008/09 performance data (the latest available); this was used to identify those with the best and worst rates of improvement, ensuring that the most diverse perspectives on modernisation and its legacy were presented.

The paper is structured as follows: First, rather than conducting a traditional literature review, this study uses a critical discourse perspective to review the policy language from four 
white papers during the period of modernisation. The purpose of this policy review is to identify the intentions behind, and language of, modernisation over time to better understand what this change agenda actually represented for the public sector and public managers in England. Next, drawing on qualitative interviews with local government workers post-modernisation, we examine the legacy effects of modernisation as experienced and understood by those at the forefront of public service formulation and delivery. The paper closes with conclusions and reflections drawn on the future of the public sector for its workers.

\section{Policy Review}

In UK political and legislative processes, a white paper is a formalised statement of policy goals and the political forewords to white papers (i.e. opening statements that were written by sponsoring politicians) represent an attempt to encapsulate the intent behind the action. Whilst still subject to change, they articulate political ambitions and are drawn upon here for the purposes of content and discourse analysis to offer a clear picture of what the modernisation agenda signified for the public sector in England.

\section{The Modernisation Agenda}

During the early period of New Labour's administration, the primary focus of modernisation was on continuous improvement and this was outlined by the first Modernising Government White Paper (Cabinet Office 1999, p.5), which stated that "modernising government is a long term programme of improvement". This was expressed as a legal duty to deliver continuous improvement in local government functions, driven by economy, efficiency and effectiveness (DETR 1999). Central to this was the wide scale implementation of performance measures, which 
included the mandatory Best Value performance indicators (BVPI), and carried an expectation that local government would further develop its performance management to include other services not covered by BVPIs but that were significant to the achievement of local ambitions. Individual indicator levels of performance were classified by relative ranking from the best performing authority to the worst, as well as forming part of the heuristic judgements within the overall regulatory assessment mechanisms; this was a direct move towards benchmarking performance, which attempted to measure (and compare) rates of improvement across and between local authorities and, thus, to influence performance by publicising comparisons (Ashworth et al. 2009). Modernisation required authorities to more effectively manage their performance, to submit to external assessment and judgement, and to embrace the 'best' external practice, including opportunities offered by the private sector - all in the pursuit of 'Best Value' (DETR 1999). This placed a statutory duty on local government to make arrangements to secure continuous improvement in the way in which its functions were exercised (DETR 1999). Central government ensured that local government delivered on these goals by creating "a plethora of performance indicators, targets and standards...all reinforced by the growth of inspection and audit" (Newman 2002, p.83). The rise in audit and control imposed by the modernisation agenda and in particular the role of inspection and awards such as Beacon Council (Rashman and Radnor 2005) created a 'new' performance discourse. Authorities responded to this by developing specialised corporate performance teams who engaged with this performance discourse and the associated language of inspection and regulation.

Collectively, what emerged during the modernisation agenda was a sense of strongly directive discourses around continuous improvement and performance management, consistent with NPM approaches. NPM has been criticised for automatically privileging the private sector 
and its approaches over the public sector (Allison 1986; Walker et al. 2011) and yet the private sector is not a single, homogenous community that shares a common goal set. Clearly, there is much good practice within the private sector regarding performance and improvement that is also valuable and useful within the public sphere and, internationally, public bodies have been encouraged to 'modernise' for some time by mimicking private sector practices (Osborne and Gaebler 1992; OECD 2004). However, the development of the discipline of public management and the influence of the private sector has invoked several issues with the translation of approaches from one sector to the other (Osborne et al. 2013; Osborne et al. 2015; Radnor et al. 2016).

\section{The Language of Modernisation}

Forewords of the four key modernisation white papers offer the most succinct distillation of central government ambitions, with content and discourse analyses deemed an effective way of assessing the notable themes and ideas of each white paper. This advances a key concern of our analysis by examining 'how the organisational context functions as a site of struggle over identity and meaning' (Talbot et al. 2003, p.74). Table 1 provides a content analysis of the four white papers that underpinned the modernisation agenda in England. A reading of the forewords generates a list of key 'principle' words that form the basis of political intention, such as 'modernization' or 'community'. As Fairclough $(2000 ; 2013)$ notes, the power of language to convey a set of encoded meanings suggests greater attention should perhaps be paid to the 'how' of political communication and not merely the 'what'. The key terms were tested and consolidated into a more parsimonious set. Wildcards $(*)$ were used to capture non-significantly different variations of the same word so 'communit*' covers 'community', and 'communities' for instance, while lexicallysimilar items were also grouped together such as 'poor', 'poverty', 'impoverished'. For each key 
term the number of occurrences is captured along with the percentage that this term represents of the total number of key terms within the foreword; here, we use a percentage of the total number of key terms that adds to $100 \%$ and highlight in grey shading the five most frequent terms used. For example, in the 1999 Modernising Government foreword, 'government' appears 36 times and this equates to $42 \%$ of all the key terms found in the analysis of that white paper.

\section{...Insert Table 1 About Here...}

We observe from the content analysis that the terms 'government', 'modern*' (e.g. modernised, modernisation, modern) and comparative terms of 'good, better, best' (such as "we will make sure that government services are better") account for $75 \%$ of all the coded terms found in the 1999 paper. As a white paper at the beginning of an administration, this paper is dominantly focused on two things: being 'forward looking' and the 'role of government'. 'Modernising Government' is capitalised and written as a proper noun - a product, a tangible, empirically-realist entity that is distinct from simply 'modernising government' as identified by the lower case. We contend that this white paper foreword employs what Fairclough terms 'overwording' around the concept of modernisation, indicating that this is a "focus of ideological struggle" $(2001, \mathrm{p} .96)$ in which government intend to prevail, establishing and imposing a new vision for local government. The white paper's vision quickly establishes the field of play, such that government is now "not hidebound by the old ways of government" (Cabinet Office 1999, p.9). Whether the approaches proposed are completely new, however, is contestable, given that we can fit them into a paradigm of NPM that extends in at least some ways the direction charted by the previous Conservative administration (Stoker 1997; 2003).

Whilst remaining a focus, modernisation as a term disappears after the 1999 paper; the government retreats from this rhetorical 'overwording' and its plans for what modernisation actually means in reality begin to emerge, with the focus moving from what government 'will do' 
in the general sense of what it will do for communities specifically. Local government becomes much more prominent in terms of carrying the burden of responsibility for delivering central government's ambitions, leading to local government being told what its ambitions should be. For the 2006 white paper, a small number of terms dominate the language used, strongly reinforcing messages about the role of government and the local discourse for communities. The 2008 and 2011 papers are much lighter in content. Not only do they both have a lower ratio of key terms to general word count, but the top five terms account for significantly less of the overall message content. Here modernisation gives way to reforming and democratising. These two papers are, therefore, more varied and softer in their respective message tone, relative to the 1999 and 2006 white papers. One explanation for this is that the 2011 white paper reflects a change of administration in 2010 to the Conservative-Liberal Democrat coalition, which saw the removal of the statutory assessment frameworks, and the bulk of performance reporting requirements (that had been prevalent under modernisation).

The discourses of these four white papers are summarised below in Table 2, which we aggregate to examine policy trajectory of performance and service reform over time. Appendix A illustrates in further detail how the distribution of key words changes across the four white papers as the modernisation agenda progressed and ultimately ended, at least formally, with the coalition government in 2010 .

\section{...Insert Table 2 About Here...}

Returning to our first research question: what was the intention behind modernisation? The terminology used to describe and implement modernisation is far from being neutral of "cognitive content' but rather plays a key role in influencing opinions and attitudes towards it. If discourse is a physical act, and the construction of sense and meaning is both ambiguous and dependent on the 
notion of reference, then the language of modernisation - the key discourse to have faced contemporary local governments across core NPM countries - is a critical one. The very term 'modernising government' is emotive, used to suggest the public sector was previously 'not modern' and that the new approach represents a transformational change. Modernisation, then, is used to suggest dissatisfaction with the status quo and that what exists is somehow insufficient. The strengths of the public sector were, therefore, not generally articulated, while the perceived weaknesses were emphasised in the introduction of modernisation; for instance, "... some parts of the public sector are as efficient, dynamic and effective as anything in the private sector. But other parts are not." (Cabinet Office 1999, p.11). As this programme of reform progressed the narrative was one of control and prescription by central government to local government who were effectively instructed and 'told' what to do and what is expected to implement modernisation. While the importance of community became more heavily emphasised this message was again delivered in a top-down manner, which questions the level of engagement and input the modernisation agenda actually sought from public managers and local communities despite the attached importance to these groups.

Clearly the motivation, then, was one of radical change to the sector but what were the consequences of this change agenda for public sector organisations? And, what have been the responses of senior and middle management employees to the legacy of modernisation?

\section{Modernisation: A Success or Failure?}

In reviewing the four white papers that trace the introduction and abandonment of modernisation, we sought to establish what the modernisation agenda signified. As Fairclough (2001) argues, the language used to define and implement modernisation cannot simply be taken at face value and is a socially conditioned process. In practical terms, it is almost impossible to establish the success 
of the modernisation agenda as an 'outsider looking in', as the overall goals are either difficult to measure or poorly defined. This partially explains the view that NPM struggles to articulate its impact and the benefits of 'modernising' services/institutions are taken more as an article of doctrinal faith than an evidence-based agenda for improvement (Pollitt 2013; Pollitt and Dan 2013). In 2010, the main assessment regimes for local government were removed by the Coalition Government, which served to dismantle the directive and more coercive elements of the modernisation change agenda. There have been some distinct advantages to this, but these advantages must be set in the context of significant budget cuts for local government of up to $60 \%$ (LGA 2015). To better understand the effects of modernisation and the legacy effects of this change agenda, it is necessary to examine the experiences of those that have, and continue to be, directly impacted: public sector workers. We now explore the consequences of this change agenda for public sector organisations as experienced then and now by their employees across six English local authorities.

The six local authorities sampled are unitary authorities, which are 'single tier' authorities delivering the entire range of public services offered by local government in England (i.e. environmental and regulatory services, economic development, education, social care, culture and leisure, etc.). Unitary authorities represent large cities and metropolitan areas, including London. Since the focus of our second research question is to examine the impact of modernisation on 'service improvement', we felt it necessary to focus on those authorities that were responsible for the full range of service provision. Therefore, two-tier authorities that cover smaller towns and rural areas, and where each only delivers a limited range of service such as housing, education, social care, and libraries were not targeted. The authorities in this research represent a range of demographically diverse communities. Table 3 describes the managerial level of interviewees 
within each case authority. 'Corporate management team' indicates an interviewee who sits on the senior-most management team in the organisation (e.g. usually the chief executive and executive directors) and also refers to the cabinet member (councillor) responsible for performance. 'Departmental management team' means the next layer within the organisation such as the management team of individual departments (assistant directors, heads of service). 'Service management teams' are the next level down again and usually managers of individual public services. Interviews were recorded and transcribed, and were analysed by travelling back and forth between the transcripts and the content analysis of the four white papers. Interview data were qualitatively analysed using an inductive coding process (Zimmermann et al. 2015) that resulted in a set of qualitative themed statements and then first order codes, which were clustered into four aggregate dimensions. This coding process was the result of a cyclical, inductive process of textual analysis.

\section{...Insert Table 3 About Here...}

\section{Skill Deficiencies and Staff Reductions}

Local government employment levels are now at the lowest levels ever recorded (Office of National Statistics 2016). Field observations and discussions with interviewees confirmed that all local authorities felt there had been significant reductions in the number of staff working within both central and departmental teams. Voluntary severance played a key part here and in one focus group alone at Stocks Green all six members of staff were waiting to hear that day about whether their voluntary severance had been approved. The overall reduction in staffing had then subsequently stimulated an increased desire to leave amongst the remaining staff members. This clearly had an impact on their ability to manage their services during this period and many interviewees suggested that those who had received early severance, which in earlier rounds had 
been on enhanced terms, were the 'lucky ones'. This is illustrative of the mentality held by workers in this post-modernisation era, as elaborated on:

The team has lost a lot of experienced colleagues. There is a lot of disillusionment, particularly as we've gone through this voluntary severance process. A number of our officers have applied for voluntary severance. (S3 DEPARTMENTAL)

The reduction in staff numbers was accepted as a feature of the organisational environment and in conversations outside the interviews, participants often made reference to the size of these reductions, particularly whilst walking around the council facilities. Interviewees were keen to illustrate the magnitude of the reductions made often pointing out the number of vacant desks and offices to further illustrate their points. These staffing reductions were not focused on any one level of management and affected many levels of the organisation, including senior management:

I think the number of heads of service that we've got, the number of directors we've got, we've got three directors and 15 heads of service, compare that to even four years ago when I think there were five directors and 25 heads of service. There were over 30 and we're now 18 (M3 DEPARTMENTAL)

Like many service organisations, staff members are the main resource for public service delivery and modernisation implemented interventions that were aimed primarily at influencing or changing staff, rather than the institution itself. However, the subsequent reductions in budgets available to authorities in light of austerity were deemed to be achievable only by losing staff members. This had been deployed through early voluntary severance in many cases, including at Castle Gate, Stocks Green, and Long Reach.

Reduction in staff appeared to drive concerns among local government employees with regard to the lack of capacity of staff to deliver services, particularly given the delivery challenges raised by the extent of the cuts, loss of staff skills and/or capabilities, and reduced commitment to working in local government. This has had a significant impact on employee public service motivation and 
the decreasing intrinsic value that they attach to their work is in sharp contrast to the typical contention that employee motivation and commitment is strongest in the public sector relative to other sectors (Lyons et al. 2006). For instance, as a departmental manager states:

...to go from a, you know first class national profile Trading Standards Service, to one that has six employees now from eighty-six ...it's just incredible. Yeah, so I think nationally we're struggling. (B3DEPARTMENTAL)

This disengagement of staff was mentioned along with a sense of the challenges being faced by employees operating in a climate of change and unpredictability. Several field observations suggested that staff were finding it difficult to maintain enthusiasm and motivation for service provision when faced with threats to their job security. As Mostafa et al. (2015) observe, security is a strong determinant of employee commitment and its absence can be expected to reduce employees' sense of identification and ownership with the service, damaging service effectiveness. This links closely to the concerns raised about the capacity and capability of the corporate teams to support service improvement work, with departmental staff raising concerns that 'they haven't got the capacity to support us, and in some senses haven't got the expertise'. At Merry Park this was explicitly expressed with concerns about the gaps in skills and knowledge being created by a loss of staff as part of a process of attrition due to budget cuts.

...there was a hole left because I ran the computer systems and I understood the planning, yes. Well, it sounds big headed, I added value in a way that I couldn't articulate when they said, "Well what would happen if you went?" You can talk about all the added value but you know your job description says that so actually, we can get rid of that team leader and that team leader can look after support. (M5 SERVICE)

This inability to quantify the value-added by employee action was a fundamental issue for employees in an environment that seemingly sought to attach a quantitative value to everything. Even if those cuts had created a 'leaner' set of staff responsibilities and staffing structures from an administrative perspective, the loss of staff expertise in specific service areas created a skills-gap 
and was creating the potential for future problems. It was clear that long-served staff and experienced middle management, whom we refer to here as the competent middle core, had left many of the case organisations creating knowledge and competency voids which they had once filled.

Coupled with the staffing level issues, a range of different skills was articulated that were also needed to deliver against future requirements that differed to the previous rhetoric of modernisation. These tended to cluster around the skills required to work in a more commercial or commissioning-focused manner, as a pragmatic approach to the drive for efficiencies, which appeared to have weakened the domain of professional expertise among authorities:

[...] I think increasingly we'll need less of that [professional expertise] and more of commissioning and project management skills...because we won't be delivering school improvement... as such, we will be facilitating and brokering that. (BI DEPARTMENTAL)

Thus, whilst modernisation may have aimed at generating momentum around 'service improvement' as enhancement of the existing skills base, the realities of austerity and budget reductions has driven new requirements for staffing and skills (Lodge and Hood 2012) that were not previously needed. Despite reduced funding, several case studies were implementing a new management or leadership development programme in contrast to the historical view that training and development outside of front-line staff is the sort of activity that is often cut early when organisations face austerity (e.g. Jewson et al. 2015). Part of that management development included approaches to generic management skills, certainly in Rudgeway and Long Reach where they were making "a big shift towards taking more commercial approaches to things" and holding managers to account, which is reflective of the need for new capabilities to face a changed public sector environment. When coupled with the demands placed on remaining staff by the loss of skills and the 'competent middle core' that provided essential management 
capacity this raised the issue as to whether existing staff were currently 'fit for purpose' and was

aligned to the move toward generating different skill sets among managers particularly:

Making sure that our managers and leaders are fit for purpose in order to deal with the change. (C3 SERVICE)

They need project management skills...They also need change leadership skills, they need that ability to go into a room and read the mood and adapt to that. And they need to be good listeners because they need to actually pick up on, not just what people are saying but what they're not saying ...(L4 CORPORATE)

As a means to stimulate the development of necessary new skills and capabilities, Long Reach was also attempting to link individual performance to pay - something that authorities had generally tended to move away from in previous years - and thus encouraging a focus on new objectives related to managing change, as opposed to managing services under modernisation. This strategy, however, prompted concerns from Long Reach and Merry Park about whether appraisals themselves were likely to achieve this objective as managers would struggle to act in a sufficiently objective manner or have 'difficult conversations', a metaphor often used by senior managers to describe the process of securing agreement to service cuts.

[...] we're introducing an individual performance framework...I'm saying you can't link it to pay because currently, people are so uncomfortable having the conversation that you'll end up busting your budget! [laughs] (L5 SERVICE)

If you looked at last year's performance appraisals... There weren't very many in the inadequate or unsatisfactory and there was an over-population in terms of the excellent or outstanding. That, probably, indicates that the manager perspective of assessing performance against shortterm objectives isn't as systemised as it needs to be. I put myself in the same category. It's actually quite hard. It's quite labour intensive doing that really well but, as an organisation, I don't think we've been terribly good for many years in terms of performance appraisal. (M4 SERVICE)

The above quotes illustrate that whilst new initiatives are being pursued to develop new skills, there is a general lack of expertise to bring about such change, which is itself an indication of the skill deficiencies present across authorities. As well as the skills gaps caused by changing 
requirements from modernisation to austerity-driven change, which requires new skills (Lodge and Hood 2012) around transformation, morale problems caused by the organisational and structural change were creating further difficulties for senior staff to attempt change; whilst often they themselves were being subjected to potential job cuts and uncertainty.

\section{Self-Policing}

The intensive nature of the regulatory systems under the modernisation agenda meant that corporate performance teams had developed to service the requirements of the modernisation agenda's regulatory regime; both departmental and corporate staff referred to this as 'feeding the beast' or 'feeding the machine' - one interviewee described it as a 'monkey on your back'. Deregulation coupled with the harsh financial environment changed the role played by corporate performance teams. Corporate teams themselves had reduced in size overall, although this is perhaps unsurprising given the overall reduction in staff levels witnessed across all local authorities. Most case studies had either retained a centralised performance team or were in the process of centralising or re-centralising teams. Notable exceptions were found in most children's and adults' social care and education services, where the ongoing data requirements from Ofsted and the Care Quality Commission (relevant regulatory bodies in England) and the relevant central government departments have meant the retention of resources in those areas. For most of the case studies, these staff, however, did not see themselves as part of the organisation's corporate performance capacity. This was also visible in the focus groups, which comprised corporate and departmental performance staff. The split role played by performance staff meant that an 'us and them' divide was clearly visible in interview responses where one part of the organisation retained an inspection or policing role. This polarisation of corporate performance staff contributed to 
conflict between corporate and departmental staff. Corporate teams had been closely associated with the modernisation agenda and were viewed by some as tools of central government rather than supportive colleagues leading to a feeling of 'it's a bit of us and them'.

This was generally recognised as a negative facet that served to diminish the sense of a single collective organisation, which is particularly crucial for service improvement. Therefore, unifying efforts around achieving corporate objectives was something that staff explicitly wished to tackle, but only in a minority of cases was there an espoused effort to break down this 'us and them divide'; although this generally came from the corporate services. Whilst most interviewees in departmental roles were broadly positive about the role of the performance team in the centre, Rudgeway's social care performance lead felt that the corporate centre cost too much money and that this should be diverted to protect 'priority areas', which we can reasonably assume meant social care. This sense that corporate teams were a drain on valuable, client-facing teams such as social services perhaps overstates reality; for instance, even the most expensive corporate performance team cost significantly less than the social care funding gap. This again illustrates the divisive culture that serves separate to performance staff from others, which is a remnant of modernisation and its performance language that excluded others outside of this function.

Overall, most corporate interviewees felt that performance teams (in the sense of those corporate teams charged with coordinating corporate performance reporting and interfacing with the Audit Commission) had lost a key part of their role, i.e. their interface with regulatory mechanisms, which udder modernisation was the source of their legitimacy. This gave rise to a sense of existential reflection with interviewees questioning what their purpose now was, with comments made such as 'why am I really here?'. Corporate performance reporting was continuing in most authorities, although with reduced numbers of indicators which provided greater autonomy 
for self-policing. However, deregulation had not significantly changed the relationship between central and departmental performance teams, despite the freedom to set more localised performance frameworks, demonstrating an unintended modernisation legacy effect.

\section{Commissioning and Service Reduction}

The performance regime that characterised the modernisation agenda was conceived in a mind-set of continual public sector growth, including instructions to provide additional 'stretch' performance through contractual-style mechanisms such as local public service agreements. Importantly, though these were additional demands on local authorities they were often accompanied by additional funding sources to help ensure effective implementation. This notion of additional funding to achieve additional performance changed with the 2010 Coalition administration. Global financial circumstances were used as justification for reducing state expenditure and further devolution of responsibility to local government under the reform of localism (Localism Act 2011). Yet, despite the rhetoric of local control and determination the enormous number of performance measures and demands for ever-improving services as championed under modernisation effectively tied the hands of local governments and local politicians. As Townley et al. (2003, p.1060) observe even the 'experts' had trouble explaining what some of the key modernisation terms meant and as such "the criterion of comprehensibility for the validity of the reforms was soon undermined". Moreover, post-modernisation, Castle Gate's head of corporate performance also felt that there had been a drift away from a focus on partnership working for service improvement towards commissioning for short-term efficiencies to reduce the cost of perceived added bureaucracy that partnerships created:

[...] you lose the corporate memory, you lose the partnership memory, there's not that many people who have been around for the whole duration, and maybe some of the ones who have are the ones who just saw it as bureaucratic. (C7 DEPARTMENTAL) 
Both Long Reach and Rudgeway had made use of outsourced arrangements for key services, described as 'partners'. In both of these cases, partnerships had recently been dismantled. One Long Reach manager questioned the wisdom of externalising the customer services interface and also recognised that the ability to control service costs relied on these being provided in-house, or perhaps through commissioning, which tended to focus on smaller service units, contracted for shorter periods, as opposed to traditional outsourcing arrangements over a longer-term. Staff in several organisations recognised that commissioning was not so much a mechanism for service improvement but usually for cost reduction, as one interviewee appropriately phrased it: "your mess for less". Here, the focus has moved from improvement driven by the values of modernisation to cost reduction driven by austerity, so rather than adopting a 'how do you improve approach' to partnership working that was common during modernisation, authorities were 'bringing it all back in-house. So, we are now a deliverer and a commissioner again'.

The discussion of 'partnership' that was forged under modernisation was broken down into historic partnerships, intra-organisational working between the corporate centre and service department, outsourced partnership arrangements, and working across the public sector. Though a strong rhetoric around partnership existed during and immediately after modernisation, in many instances, services were being insourced back to the local authority to allow the authority to generate and claim more savings; again illustrative of the move away from service improvement to pragmatic cost-based decisions. In facilitating this change, corporate change teams reported difficulties in engaging some service departments in the discussion and debate around service commissioning, particularly where this was pseudonymous for cuts. Additionally, the lack of consistent performance management and analysis capacity described by several authorities, which was a direct fallout from the reduction from the vast performance measures imposed through 
modernisation, had led to a sense of 'cutting what can be cut' rather than more considered service reductions. Again, this may be due to the scale of the cuts imposed by central government, which have meant no service has escaped the requirement to reduce costs but also illustrates the substantial shift from seeking continuous improvement and growth under modernisation to a principal focus on pragmatic cost reduction. A key part of the discussion around value for money was the motivations underpinning commissioning. It became increasingly apparent that the role of commissioning was to reduce costs as opposed to service improvement, used as a tool for service reduction to achieve the required budget cuts. This was particularly evident in Rudgeway:

[...] the context in which we're discussing it: we've got to save money, so let's do some commissioning. (R3 DEPARTMENTAL)

Here, as in other authorities, commissioning is used without clear and agreed definitions. A commissioning director in Castle Gate said that "nobody has a bloody clue what commissioning is'. As with modernisation, the term is presented as both as a neutral managerial term, yet viewed as emphatically positively-coded by some, and received negatively by others. This inherent polysemy is perhaps at the heart of the tensions between service departments and the corporate centre, who were often seen as the implementers of unwelcome 'regulation' on behalf of central government.

\section{Implications for public sector workers}

Returning to our second research question: What has been the legacy of this change agenda for public sector workers? The differing needs and concerns of different local authorities were clearly not recognised in the modernisation agenda. For example, the Comprehensive Performance Assessment (CPA) literature (the assessment regime for local authorities borne out of the modernisation agenda between 1999 and 2010) stated that deprivation does not have any bearing 
on an authority's ability to deliver services; yet this has been challenged (Andrews 2004). This demonstrates a clear tension between what was being said (the rhetoric), and what local government experienced (the reality). The subsequent loss of centralised direction and the significant budget cuts faced by local authorities arising after modernisation has had a detrimental effect on local authorities' capacity and capability to deliver vital public services. We contend that it is not enough to assess the notion of modernisation on its own merits due to the vagueness and ambiguity of its goals, but it also needs to be understood from the viewpoint of local government employees to better understand the consequences of change in public sector organisations and the reactions and responses to this change agenda of those individuals directly involved in service delivery.

The findings from the qualitative data analysis are integrated within Figure 1. Here, the legacy of modernisation is situated within an environment that it helped, in part, to create: characterised by deregulation, budget reductions, and the search for cost efficiencies. Within this environment, the consequences of change as reported by local government employees are Staff Reductions and Skill Deficiencies, and the Loss of a Competent Middle Core, while the performance outcomes of modernisation as reported by interviewees are Commissioning, Service Reduction, and Self-Policing of performance, which remains divisive as was the case under modernisation, albeit with more regulated performance measurement through central policing as opposed to local authority self-policing.

\section{...Insert Figure 1 About Here...}

Perhaps unsurprisingly, staff reductions have caused morale problems given that the expected workload has not significantly reduced, while 'customer' expectations continue to rise, which collectively places pressure on the remaining staff body. One of the main effects of this 
reduction in staff numbers has been the loss of an experienced core of staff in the middle of public organisations' hierarchy and their skills, i.e. the loss of the competent middle-core. Graduate trainees, apprentices and volunteers were all being used to various degrees to fill those gaps where funding permitted. Though each of these three groups is considerably cheaper than some of the experienced staff lost, they are not necessarily as well equipped; indeed, such new recruits were referred to as 'green' by one interviewee. That is not to say that such individuals cannot add value - they absolutely can - however, the large stock of tacit knowledge that for many local authorities can be considered central to their capability development has been either substantially eroded or altogether lost. For instance, local authorities have a series of established professional disciplines (planning, engineering, law, HR) and interviewees expressed concern that these skills were being lost and that the new apprentices were not receiving adequate training as the authority was not fully committed to their development; this was despite new recruits being given even greater responsibility than had previously been allocated to such roles.

It was suggested that more advanced training and development of employees had actually started to wane (e.g. Master's degrees), one example given is that financial certification progression (e.g. from AAT to chartered accountant) had been frozen for staff. This could be argued as a false economy given the severe financial circumstances facing local government authorities, which has only served to hasten the loss of staff, as other partner organisations such as National Health Service bodies are seen as providing more stable and secure working environments with stronger professional development prospects. Moreover, not only do inexperienced staff members lack professional skills they also lack the skills necessary to navigate organisational and institutional challenges, especially around working with elected members. This 
is not wholly negative, however, as fresh perspectives have challenged the status quo driving some innovation, which was an aim of modernisation (DETR 1999).

\section{Conclusion}

The modernisation agenda represents the epitome of a core set of NPM-oriented countries that have pursued service improvement relentlessly through ambitious programmes of reform, of which modernisation is one example. Upon its introduction to England and the rest of the UK in 1999, government policy treated 'modernising government' as if it were a universally-agreed, researchproven agenda for changing services, yet it failed to make a convincing case for this. This may be explained by the high political interest in getting immediate change as opposed to careful consideration of the long-term implications of such programmes (Maddock 2002). That is not to say that the ethos behind modernising government is 'wrong', neither is some of the reality of practice unnecessary or unwanted in the sector. Rather, the package was treated as a single, whole entity, and appeared to neither stimulate nor accept any challenge. Instead, modernising government represented a political rather than a managerial discourse (cf Andrews 2010). It

presented a series of 'woolly' statements that, in retrospect, are difficult to disagree with and then operationalised them through strongly coercive assessment regimes (Newman 2001). Entwistle and Laffin (2005, p.215) observe that this "motherhood and apple pie" explanation of reforms was used to effectively neuter union opposition to changes through creating an unsupportable dichotomy of 'in favour of improving services' against 'not in favour of improving services'; but arguably, this also prevented any direct involvement of key stakeholders such as public managers and local communities in the development of the modernisation framework, despite their explicit inclusion in the early- and mid-modernisation white papers. 
Modernisation is a loaded term, which is contested and more closely focused on the national political agenda rather than one recognised by local government authorities and their employees. Modernisation was operationalised in very specific ways in the policy and assessment frameworks that grounded notions of performance management and measurement in the sector (Andrews 2010) and was predominately operationalised as a controlling mechanism at the local level - under the guise of continuous improvement. Local authorities responded to this change agenda and many developed staffing and organisational structures to meet the administrative demands of the regulatory system. It is unclear, however, if this genuinely increased capacity to improve, or merely to 'play the game' of assessment (Newman 2001; Moxham 2013); indeed, if the latter then it might be no surprise that modernisation failed to deliver on its intentions given the associated disengagement of public managers and local authorities (e.g. Maddock 2002). Now that these have been removed, what has been the legacy impact of modernisation? Interviewees accept that inefficiencies were driven out to a degree, but local authorities are now struggling to sustain current offerings let alone strive for improvement in the context of austerity and reduced funding; suggesting there may be limitations on the extent to which modernisation did focus on actual improvement. Ironically, those authorities that adhered less to the rhetoric of modernisation appear to have actually experienced fewer complications during austerity than those who closely adhered to the rhetoric. As Andrews et al. (2003) note, failure to embrace all of the elements attached to modernisation might actually be beneficial for service performance.

The unintended effects of the modernisation agenda demonstrate the difficulties experienced in service delivery and this points to a need to revisit the success of previous large change programmes, as the lagged effects may show a different picture to that championed during large change programmes in the public sector or the immediate reports documenting success 
shortly after execution. This is a concern since what gets reported in the media about government performance and major public initiatives may well be disconnected from the actual experience of users/workers, resulting in inaccurate news coverage on their impact (Bloomfield 2006). More than this, however, we draw attention to the negative side of driving continuous improvement where employees play the game of assessment as they struggle to pursue any activities beyond the day to day challenges they are faced with. As highlighted by Maddock (2002, p.15), from the early years of modernisation, "most public sector staff do want to improve services; some just do not understand why change and modernisation is necessary. Many are confused about which new programme has priority and others are doubtful that the way modernisation is being introduced will work". Again, this demonstrates that for public sector workers, the change agenda was one that was top-down and prescriptive, which is evidenced in the critical discourse analysis of the four white papers.

This study contributes new evidence to examine whether implementation of significant management reform leads to better or worse service outcomes, which according to Andrews (2010) carries substantial practical and theoretical importance. Specifically, it is clear that public sector workers were not fully consulted or engaged within the process of modernisation and whilst this was identified during the early years of modernisation (e.g. Maddock 2002) the actual legacy effects have not been considered or examined in detail. Yet, it is the lasting effects of change legacies that ultimately steer, for better or worse, service improvement over the longer term and, thus, the consequences of ambitious change programmes must be explored over time to fully understand their effects.

Accompanying this change agenda has been a period of austerity, which has skewed and dominated the consequences of the modernisation agenda experienced in England. This twin 
impetus has led to considerable reform in local government authorities and this change cannot be directly linked solely to modernisation or the need for austerity. Nevertheless, the outcome of modernisation coupled with increasing environmental turbulence is perceived by local government employees as resulting in a hollowing out of the local government skill set and a loss of a competent middle core; the very origin from which service innovation and improvement should have materialised, which has led in some cases to the abandonment of continuous improvement.

Given the continuing pressure to raise the performance of service delivery and the challenges of understanding and responding to the complexity of citizen demands, how do we re-address the consequences and performance outcomes of the modernisation aftermath? In the world of politics and public services, the rhetoric will likely always struggle to match the reality, thus, we argue there is a need to flip the power pyramid for the success of future change reforms - this will require putting local government employees and communities at the top of the power pyramid, and this transformation is depicted in Figure 2.

\section{...Insert Figure 2 About Here...}

Rather than a continuing belief in the power of central government intervention and their programmes of reform to improve public services (Andrews 2010)-which appears to be a fallacya much clearer understanding is required of the role to be played by actors at the local level in creating service value through improvement. Given the relatively new narrative of localism in OECD countries (Lowndes and Pratchett 2012), where greater power is transferred to local actors for decision-making, future research must develop where and how service improvement can be created (Osborne et al. 2013; Osborne et al. 2015). Transforming the power pyramid for future public sector change is a suitable departure to this end, repositioning the power-axis so local government employees and the communities they serve drive needed change. 


\section{References}

ALLISON, G. T. 1986. Public and private administrative leadership: Are they fundamentally alike in all unimportant respects. Leadership and organizational culture: New perspectives on administrative theory and practice, 214-222.

ANDREWS, R. 2004. Analysing Deprivation and Local Authority Performance: the implications for CPA. Public Money \& Management, 24, 19-26.

ANDREWS, R. 2010. The impact of modernisation on fire authority performance: an empirical evaluation. Policy \& Politics, 38, 599-617.

ANDREWS, R., BOYNE, G. A., LAW, J. \& WALKER, R. M. 2003. Myths, measures and modernisation: A comparison of local authority performance in England and Wales. Local Government Studies, $29,54-75$.

ASHWORTH, R., BOYNE, G. A. \& DELBRIDGE, R. 2009. Journal of Public Administration Research and Theory, 19, 165.

BLACKBURN, G. 2014. Elements of Successful Change: The Service Tasmania Experience to Public Sector Reform. Australian Journal of Public Administration, 73, 103-114.

BLOOMFIELD, P. 2006. The Challenging Business of Long - Term Public - Private Partnerships: Reflections on Local Experience. Public Administration Review, 66, 400-411.

CABINET OFFICE. 1999. Modernising Government (White Paper) [Online]. London: HMSO. [Accessed 08/05/2016].

CABINET OFFICE. 2011. Open Public Services (White Paper) [Online]. London: TSO. Available: www.cabinetoffice.gov.uk [Accessed 01/07/2014].

CHRISTENSEN, T. \& LAEGREID, P. (eds.) 2011. The Ashgate Research Companion to New Public Management. Farnham: Ashgate Publishing Ltd.

DAVID, M. \& SUTTON, C. D. 2011. Social Research: An Introduction. London, Sage Publications Ltd.

DCLG. 2006. Strong and prosperous communities (White Paper) [Online]. London: TSO. [Accessed Cm 6939-I].

DCLG. 2008. Communities in control: real people, real power [Online]. London: TSO. [Accessed].

DETR. 1999. Local Government Act 1999 [Online]. London: The Stationery Office. [Accessed c.27].

ENTWISTLE, T. \& LAFFIN, M. 2005. A Prehistory of the Best Value Regime. Local Government Studies, $31,205-218$.

FAIRCLOUGH, N. 2000. New Labour, New Language? London, Routledge.

FAIRCLOUGH, N. 2001. Language and power. Harlow, Pearson Education.

FAIRCLOUGH, N. 2013. Critical discourse analysis and critical policy studies. Critical Policy Studies, 7, 177-197.

FERLIE, E., ASHBURNER, L., FITZGERALD, L. \& PETTIGREW, A. 1996. The new public management in action. Oxford, Oxford University Press.

GOLDFINCH, S. \& WALLIS, J. O. E. 2010. Two Myths of Convergence in Public Management Reform. Public Administration, 88, 1099-1115.

HAWARD, M. \& ZWART, I. 2000. Local government in Tasmania: reform and restructuring. Australian Journal of Public Administration, 59, 34-48.

HOOD, C. 1991. A public management for all seasons. Public Administration, 69, 3-19.

HOOD, C. 1995. The New Public Management in the 1980s - Variations on a Theme. Accounting Organizations and Society, 20, 93-109.

JEWSON, N., FELSTEAD, A. \& GREEN, F. 2015. Training in the public sector in a period of austerity: the case of the UK. Journal of Education and Work, 28, 228-249.

KRIPPENDORFF, K. 2004. Content analysis: An introduction to its methodology. Sage.

KUIPERS, B. S., HIGGS, M., KICKERT, W., TUMMERS, L., GRANDIA, J. \& VAN DER VOET, J. 2014. The management of change in public organizations: A literature review. Public Administration, 92, 1-20. 
LAFFIN, M. 2008. Local government modernisation in England: a critical review of the LGMA evaluation studies. Local Government Studies, 34, 109-125.

LGA. 2015. Future funding outlook for councils 2019/20 Interim 2015 Update [Online]. London: Local Government Association. Available: www.local.gov.uk.

Localism Act. 2011. (c.20). London: HMSO.

LODGE, M. \& HOOD, C. 2012. Into an Age of Multiple Austerities? Public Management and Public Service Bargains across OECD Countries. Governance-an International Journal of Policy Administration and Institutions, 25, 79-101.

LOWNDES, V. \& PRATCHETT, L. 2012. Local governance under the coalition government: Austerity, localism and the 'Big Society'. Local government studies, 38, 21-40.

LYNN, L. E. 1998. The new public management: How to transform a theme into a legacy. Public Administration Review, 58, 231-237.

Lyons, S. T., L.E. Duxbury, and C.A. Higgins. 2006. "A Comparison of the Values and Commitment of Private Sector, Public Sector, and Parapublic Sector Employees." Public Administration Review 66 (4): 605-618.

MADDOCK, S. 2002. Making modernisation work: New narratives, change strategies and people management in the public sector. International Journal of Public Sector Management, 15, 13-43.

Mostafa, A. M. S., J. S. Gould-Williams, and P. Bottomley. 2015. "High-Performance HR Practices and Employee Outcomes: The Mediating Role of Public Service Motivation". Public Administration Review 75 (5): 747-757.

MOXHAM, C. 2013. Measuring up: examining the potential for voluntary sector performance measurement to improve public service delivery. Public Money \& Management, 33, 193-200.

NEUENDORF, K. A. 2002. The content analysis guidebook. Sage.

NEWMAN, J. 2001. Modernising governance: New Labour, policy and society. London, Sage Publications Ltd.

NEWMAN, J. 2002. The New Public Management, modernization and institutional change: disruptions, disjunctures and dilemmas. In: MCLAUGHLIN, K., OSBORNE, S. \& FERLIE, E. (eds.) New Public Manaagement: Current Trends and Future Prospects. London: Routledge.

OECD. 2004. Public Sector Modernisation: Governing for Performance [Online]. Paris: OECD.

OFFICE OF NATIONAL STATISTICS. 2016. Public Sector Employment, UK: June 2016 [Online]. London: ONS.

OSBORNE, D. \& GAEBLER, T. 1992. Reinventing Government. Reading, MA, Addison-Wesley.

OSBORNE, S. P. \& MCLAUGHLIN, K. 2002. NPM in context. In: MCLAUGHLIN, K. \& OSBORNE, S. P. (eds.) New public management: current trends and future prospects. London: Routledge.

OSBORNE, S. P., RADNOR, Z., KINDER, T. \& VIDAL, I. 2015. The SERVICE Framework: A Publicservice-dominant Approach to Sustainable Public Services. British Journal of Management, 26, 424-438.

OSBORNE, S. P., RADNOR, Z. \& NASI, G. 2013. A new theory for public service management? Towards a (public) service-dominant approach. American Review of Public Administration, 43, 135-158.

POLLITT, C. 2013. 40 Years of public management reform in UK central government - promises, promises. Policy \& Politics, 41, 465-480.

POLLITT, C. \& DAN, S. 2013. Searching for Impacts in Performance-Oriented Management Reform. Public Performance \& Management Review, 37, 7-32.

RADNOR, Z., OSBORNE, S. \& GLENNON, R. 2016. Public management theory. In: ANSELL, C. \& TORFING, J. (eds.) Handbook on Theories of Governance. Cheltenham: Edward Elgar.

RASHMAN, L. \& RADNOR, Z. 2005. Learning to improve: Approaches to improving local government services. Public Money \& Management, 25, 19-26.

STOKER, G. 1997. Local government in Britain after Thatcher. In: LANE, J.-E. (ed.) Public sector reform: rationale, trends and problems. London: Sage.

STOKER, G. 2002. Life is a lottery: New Labour's strategy for the reform of devolved governance. Public Administration, 80, 417-434. 
STOKER, G. 2003. Transforming local governance: from Thatcherism to New Labour. Basingstoke, Palgrave Macmillan.

TAlBOT, M., ATKINSON, K. \& ATKINSON, D. 2003. Language and Power in the Modern World. Edinburgh University Press.

TICHELAR, M. \& WATTS, L. 2000. Role players and authority figures: Informal power relationships within local authorities. Policy \& Politics, 28, 221-231.

TORRES, L. 2004. Trajectories in public administration reforms in European Continental countries. Australian Journal of Public Administration, 63, 99-112.

TOWNLEY, B., COOPER, D. J. \& OAKES, L. 2003. Performance measures and the rationalization of organizations. Organization studies, 24, 1045-1071.

WALKER, R. M., BREWER, G. A., BOYNE, G. A. \& AVELLANEDA, C. N. 2011. Market Orientation and Public Service Performance: New Public Management Gone Mad? Public Administration Review, 71, 707-717.

WILLIAMS, H. M., RAYNOR, J. \& ALLINSON, C. W. 2012. New public management and organisational commitment in the public sector: testing a mediation model. The International Journal of Human Resource Management, 23, 2615-2629.

ZIMMERMANN, A., RAISCH, S. \& BIRKINSHAW, J. 2015. How Is Ambidexterity Initiated? The Emergent Charter Definition Process. Organization Science, 26, 1119-1139. 
Figure 1: Local government employees' perception of the impact of a change agenda

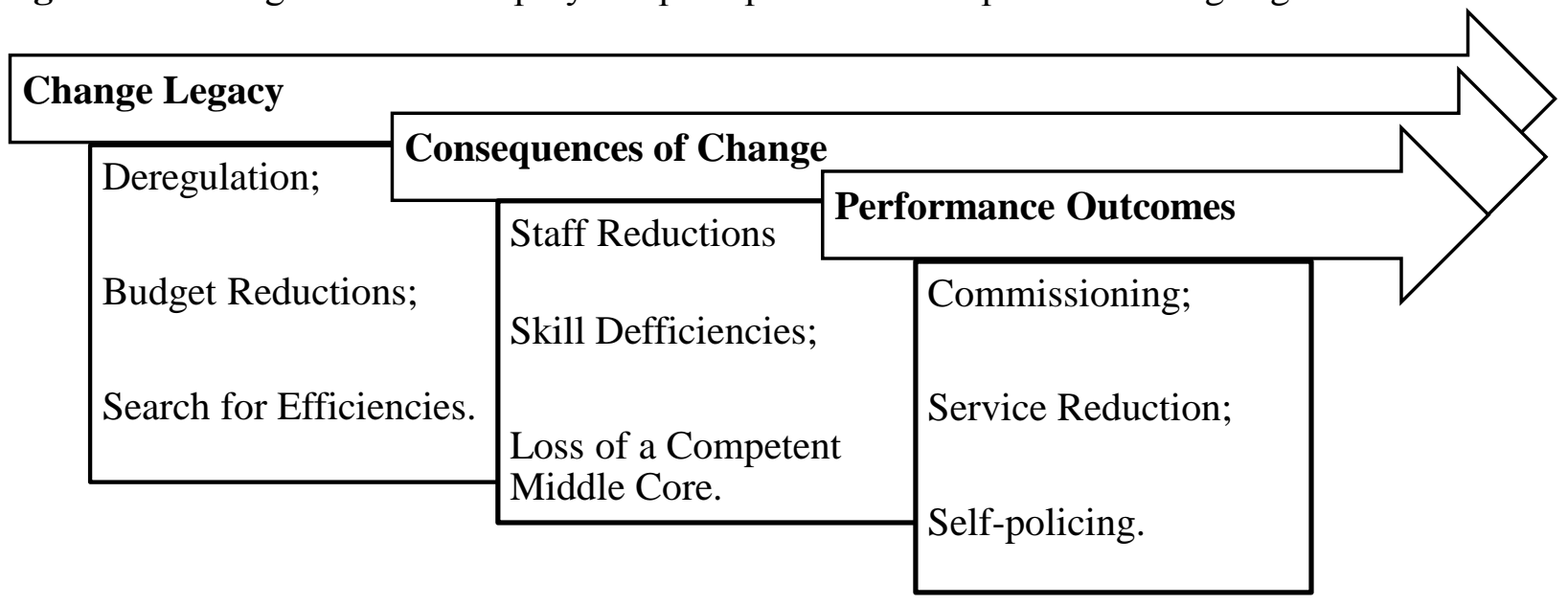

Figure 2. Transforming the power pyramid for future public sector change

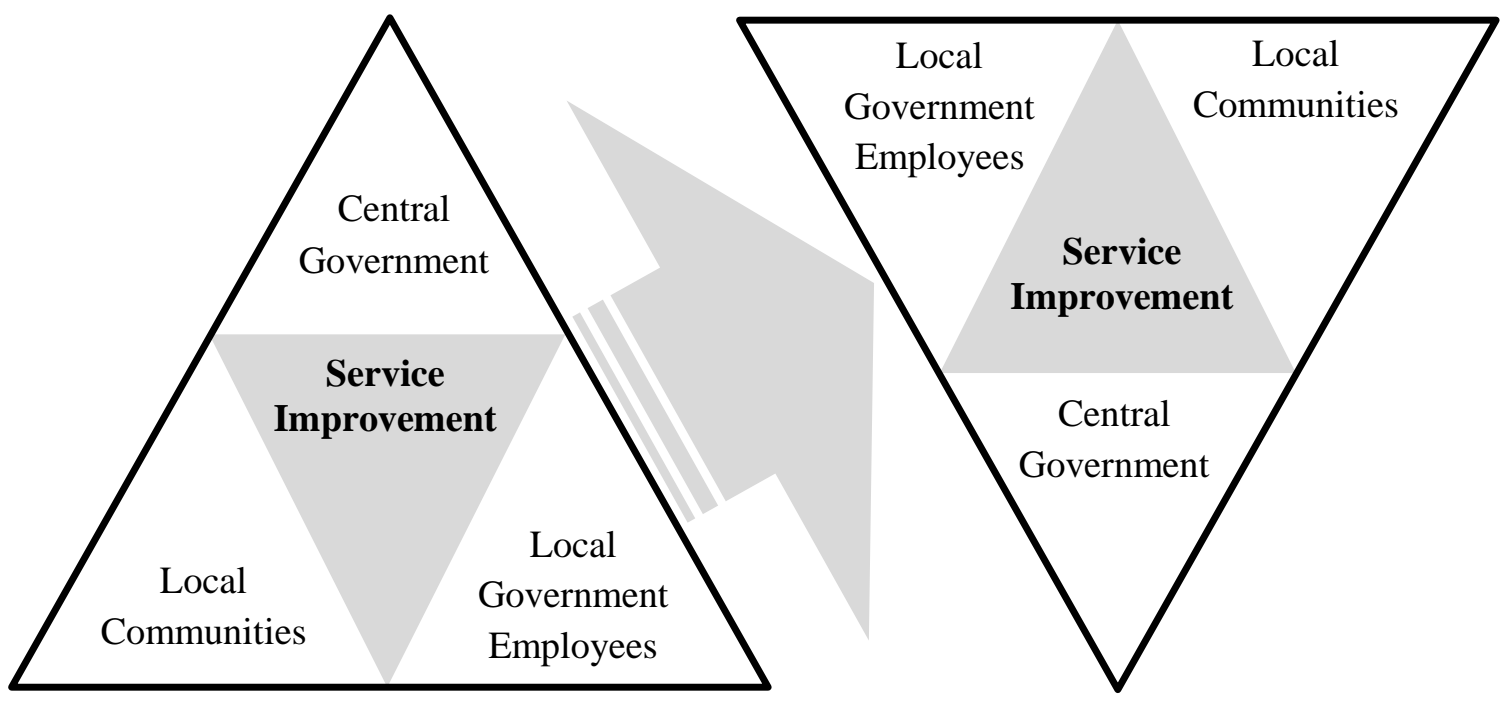


Table 1. Content analysis of four White Papers

\begin{tabular}{|c|c|c|c|c|c|c|c|c|c|}
\hline \multirow{2}{*}{$\begin{array}{l}\text { White Paper } \\
\text { Key term }\end{array}$} & \multicolumn{2}{|c|}{$\begin{array}{l}\text { Modernising } \\
\text { Government } \\
(1999)\end{array}$} & \multicolumn{2}{|c|}{$\begin{array}{l}\text { Strong \& } \\
\text { Prosperous } \\
\text { Communities } \\
(2006)\end{array}$} & \multicolumn{2}{|c|}{$\begin{array}{l}\text { Communities in } \\
\text { Control } \\
(2008)\end{array}$} & \multicolumn{2}{|c|}{$\begin{array}{l}\text { Open Public } \\
\text { Services } \\
(2011)\end{array}$} & \multirow{2}{*}{$\begin{array}{l}\text { Total } \\
\\
\text { No. }\end{array}$} \\
\hline & No. & $\%$ & No. & $\%$ & No. & $\%$ & No. & $\%$ & \\
\hline Local* & 2 & $2 \%$ & 55 & $33 \%$ & 11 & $7 \%$ & 0 & $0 \%$ & 68 \\
\hline Government & 36 & $42 \%$ & 24 & $14 \%$ & 6 & $4 \%$ & 1 & $2 \%$ & 67 \\
\hline People, communit* & 5 & $6 \%$ & 25 & $15 \%$ & 23 & $14 \%$ & 2 & $3 \%$ & 55 \\
\hline Good, better, best & 11 & $13 \%$ & 7 & $4 \%$ & 1 & $1 \%$ & 6 & $10 \%$ & 25 \\
\hline Public service* & 2 & $2 \%$ & 10 & $6 \%$ & 4 & $2 \%$ & 7 & $12 \%$ & 23 \\
\hline Citizen & 1 & $1 \%$ & 11 & $7 \%$ & 6 & $4 \%$ & 4 & $7 \%$ & 22 \\
\hline Power* & 0 & $0 \%$ & 5 & $3 \%$ & 12 & $7 \%$ & 3 & $5 \%$ & 20 \\
\hline Modern* & 17 & $20 \%$ & 0 & $0 \%$ & 2 & $1 \%$ & 0 & $0 \%$ & 19 \\
\hline New, recent & 6 & $7 \%$ & 10 & $6 \%$ & 2 & $1 \%$ & 0 & $0 \%$ & 18 \\
\hline Reform* & 3 & $3 \%$ & 1 & $1 \%$ & 4 & $2 \%$ & 8 & $14 \%$ & 16 \\
\hline Improve* & 1 & $1 \%$ & 9 & $5 \%$ & 2 & $1 \%$ & 1 & $2 \%$ & 13 \\
\hline Opportunit* & 0 & $0 \%$ & 5 & $3 \%$ & 0 & $0 \%$ & 7 & $12 \%$ & 12 \\
\hline Democra* & 1 & $1 \%$ & 3 & $2 \%$ & 6 & $4 \%$ & 0 & $0 \%$ & 10 \\
\hline Equal $^{*}$, fair* & 1 & $1 \%$ & 0 & $0 \%$ & 1 & $1 \%$ & 7 & $12 \%$ & 9 \\
\hline $\begin{array}{l}\text { Poor, poverty, } \\
\text { impover* }\end{array}$ & 0 & $0 \%$ & 0 & $0 \%$ & 0 & $0 \%$ & 6 & $10 \%$ & 6 \\
\hline $\begin{array}{l}\text { Unequal*, } \\
\text { inequal*, unfair*, } \\
\text { less fair }\end{array}$ & 0 & $0 \%$ & 0 & $0 \%$ & 0 & $0 \%$ & 4 & $7 \%$ & 4 \\
\hline Fail* & 0 & $0 \%$ & 0 & $0 \%$ & 0 & $0 \%$ & 3 & $5 \%$ & 3 \\
\hline Change & 0 & $0 \%$ & 3 & $2 \%$ & 0 & $0 \%$ & 0 & $0 \%$ & 3 \\
\hline Count of terms & 86 & & 168 & & 80 & & 59 & & 393 \\
\hline $\begin{array}{l}\text { Word count of } \\
\text { forewords }\end{array}$ & 487 & & 1,223 & & 833 & & 612 & & 3155 \\
\hline $\begin{array}{l}\text { Key term instance } \\
\text { per word freq. }\end{array}$ & 5.66 & & 7.28 & & 10.41 & & 10.3 & & 8.03 \\
\hline $\begin{array}{l}\text { Forewords written } \\
\text { by: }\end{array}$ & $\begin{array}{l}\text { Blair } \\
\text { Cunr }\end{array}$ & & Blair, & & Brow & lears & Cams & / Clegg & \\
\hline
\end{tabular}

Note: five most frequent terms are highlighted in grey shading. 
Table 2. Policy trajectory of performance and service reform

\begin{tabular}{|c|c|c|c|c|}
\hline Timeframe & $1997-2006$ & $2006-2008$ & 2008-2010 & 2010-2014 \\
\hline $\begin{array}{l}\text { Policy } \\
\text { trajectory } \\
\text { (rhetoric) }\end{array}$ & $\begin{array}{l}\text { Modernization of } \\
\text { institutions }\end{array}$ & $\begin{array}{l}\text { Emphasis on local } \\
\text { 'agency' }\end{array}$ & $\begin{array}{l}\text { Importance of } \\
\text { communities, } \\
\text { partnerships }\end{array}$ & $\begin{array}{l}\text { Equality, } \\
\text { opportunity, } \\
\text { openness of } \\
\text { services }\end{array}$ \\
\hline $\begin{array}{l}\text { Main } \\
\text { mechanisms }\end{array}$ & $\begin{array}{l}\text { Democratic and } \\
\text { organizational } \\
\text { renewal }\end{array}$ & Local plan setting & $\begin{array}{l}\text { Integrated } \\
\text { assessment of } \\
\text { more strategic } \\
\text { performance }\end{array}$ & $\begin{array}{l}\text { Budget cuts, de- } \\
\text { ring-fencing of } \\
\text { funding, } \\
\text { Commissioning }\end{array}$ \\
\hline $\begin{array}{l}\text { Consequences } \\
\text { (reality) }\end{array}$ & $\begin{array}{l}\text { Institutional } \\
\text { upheaval, new } \\
\text { organizational } \\
\text { forms, increased } \\
\text { demands }\end{array}$ & $\begin{array}{l}\text { Burdensome } \\
\text { performance } \\
\text { management and } \\
\text { regulation }\end{array}$ & $\begin{array}{l}\text { Redressing of } \\
\text { burden (but } \\
\text { development } \\
\text { halted by }\end{array}$ & $\begin{array}{l}\text { Policy vacuum but } \\
\text { goal of smaller } \\
\text { state, lack of } \\
\text { capacity, service } \\
\text { reductions }\end{array}$ \\
\hline $\begin{array}{l}\text { Approach to } \\
\text { regulation }\end{array}$ & $\begin{array}{l}\text { External } \\
\text { inspections and } \\
\text { self-assessment } \\
\text { (service } \\
\text { performance) }\end{array}$ & $\begin{array}{l}\text { External } \\
\text { inspections and } \\
\text { self-assessment } \\
\text { (strategic } \\
\text { performance and } \\
\text { capacity) }\end{array}$ & $\begin{array}{l}\text { Integrated external } \\
\text { inspection and } \\
\text { discussion }\end{array}$ & $\begin{array}{l}\text { Self-policing with } \\
\text { limited retained } \\
\text { inspection }\end{array}$ \\
\hline
\end{tabular}

Source: authors' and the white papers listed. 
Table 3. Positions held by interviewees

\begin{tabular}{|c|c|c|c|c|c|c|c|}
\hline & $\begin{array}{l}\text { Long } \\
\text { Reach }\end{array}$ & Rudgeway & $\begin{array}{l}\text { Merry } \\
\text { Park }\end{array}$ & $\begin{array}{l}\text { Castle } \\
\text { Gate }\end{array}$ & $\begin{array}{l}\text { Stocks } \\
\text { Green }\end{array}$ & $\begin{array}{c}\text { Bell } \\
\text { Tower }\end{array}$ & Total \\
\hline $\begin{array}{l}\text { Corporate } \\
\text { management team }\end{array}$ & L4 & R5, R6 & M1 & $\mathrm{C} 1, \mathrm{C} 4$ & S1 & B2 & 8 \\
\hline $\begin{array}{l}\text { Departmental } \\
\text { management team }\end{array}$ & $\begin{array}{l}\text { L1, L2, } \\
\text { L3, }\end{array}$ & $\begin{array}{l}\text { R1, R3, } \\
\text { R4, R7 }\end{array}$ & M3 & $\begin{array}{l}\text { C5, C6 } \\
\text { C7 }\end{array}$ & $\begin{array}{l}\text { S3, S4, } \\
\text { S5 }\end{array}$ & $\begin{array}{l}\text { B1, B3, } \\
\text { B4, B5 }\end{array}$ & 18 \\
\hline $\begin{array}{l}\text { Service } \\
\text { management team }\end{array}$ & L5 & $\mathrm{R} 2$ & $\begin{array}{l}\text { M2, M4, } \\
\text { M5 }\end{array}$ & $\mathrm{C} 2, \mathrm{C} 3$ & $\mathrm{~S} 2$ & B6 & 9 \\
\hline Total & 5 & 7 & 5 & 7 & 5 & 6 & 35 \\
\hline
\end{tabular}


Appendix A. Distribution of key words across modernisation white papers, 1999-2011
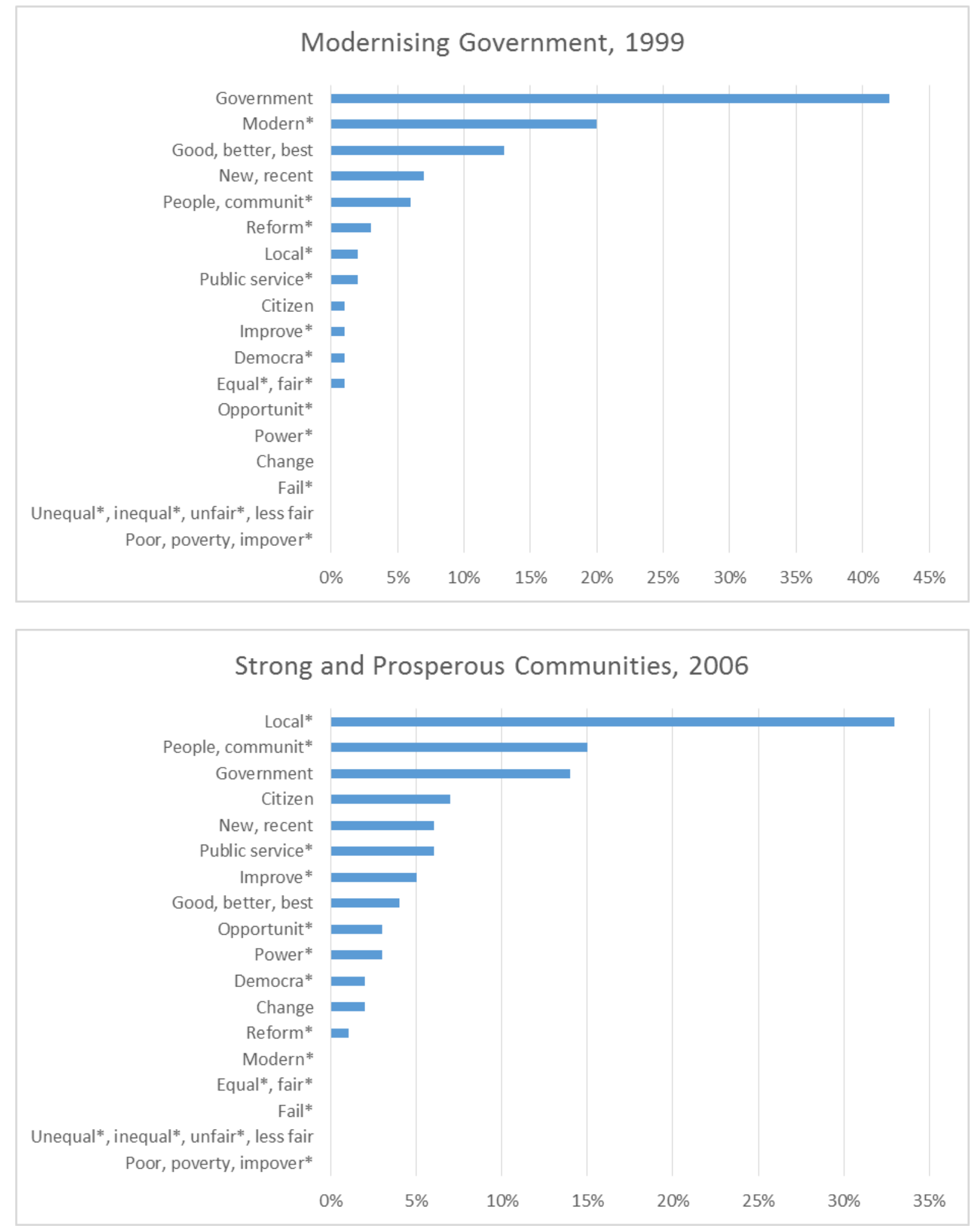

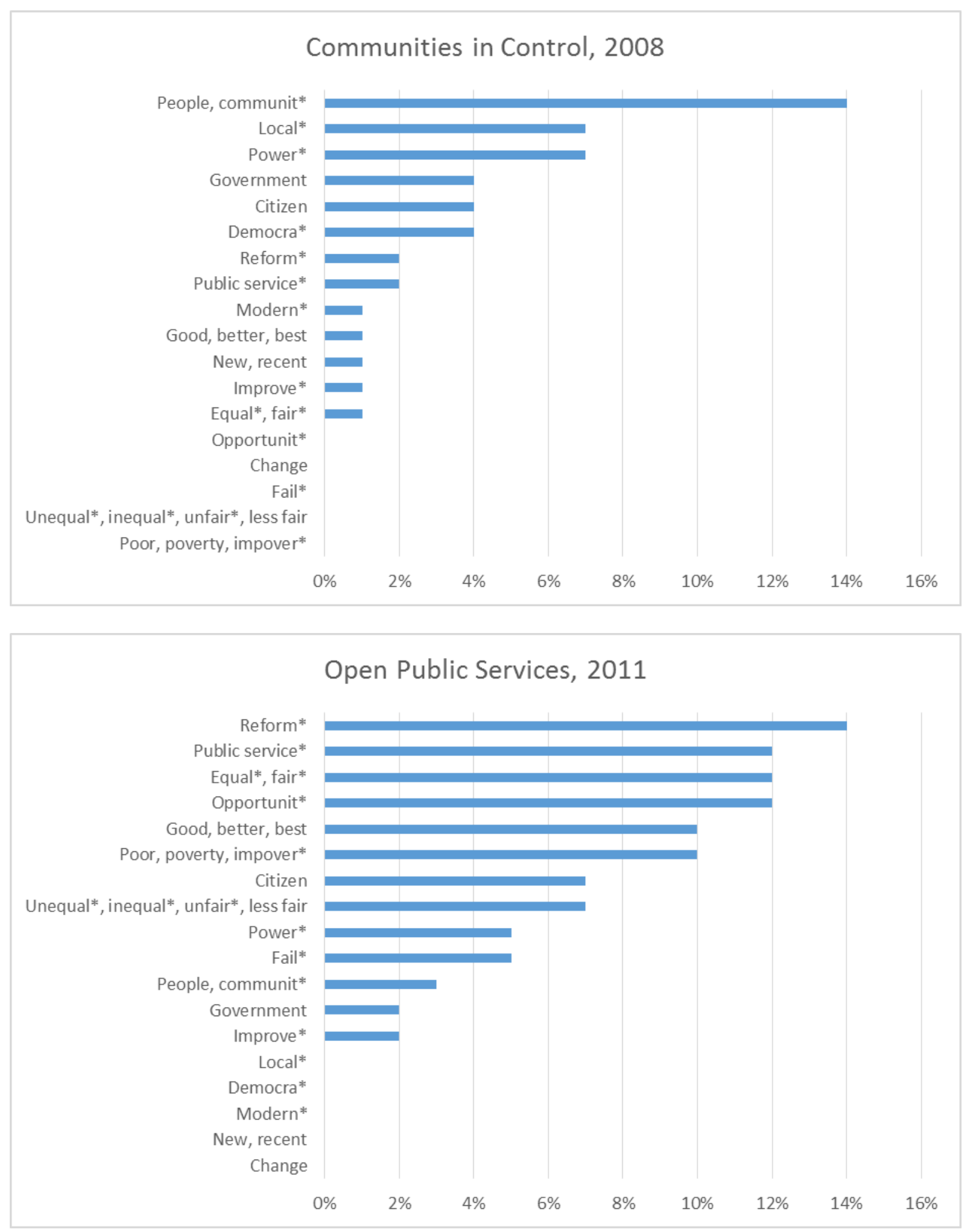